\title{
Pleistocene glacial morphology and timing of Last Glacial Cycle in Cantabrian Mountains (Northern Spain): new chronological data from the Asón Area
}

Research Article

\author{
Manuel Frochoso ${ }^{1 *}$, Raquel González-Pellejero ${ }^{1 \dagger}$, Fernando Allende $^{2 \neq}$ \\ 1 Department of Geography, Urbanism and Regional Planning, \\ University of Cantabria, Santander 39005, Cantabria, Spain \\ 2 Department of Geography, University Autónoma de Madrid, Madrid, 28049, Spain
}

Received 4 October 2012; accepted 12 January 2013

\begin{abstract}
The timing of the local last glacial maximum in the mountains of the Northern Iberian Peninsula is not synchronous with the global Last Glacial Maximum (LGM) probably due to the marginal position of the Northern Iberian Peninsula within the European continent. The study of a Cantabrian massif, the Asón platform and summits, provides new data on the extent and timing of the local last glaciation. Here we can place the last maximal extent of glaciers during Early Würm, according to OSL dating on till samples. The main glaciers developed at least between 78$65 \mathrm{ka} \mathrm{BP}$, well centred on MIS 4 and even the transition to MIS 5. The erosive efficacy of these glaciers decreased later, ca. 45-40 ka BP, until they abruptly disappeared from the edges of the massif. A new ice advance left welldefined moraines at the edges of the massif's internal depressions, indicating a tongue disjunction phase with two glacier sub-stages, probably one at the beginning of the cooling ca. 27-25 ka BP, followed by a retreat and another glacial advance ca. 21-18 ka BP. After these episodes the glaciers disappeared from the Asón Mountains and only some residual glaciers were formed that may be related to the LGM.

Keywords: Iberian Peninsula • Cantabrian Mountains • Last Glacial Maximum (LGM) • Late Pleistocene • glacial landforms • geochronology $\cdot$ dating.

(c) Versita sp. z o.o.
\end{abstract}

\section{Introduction}

The Cantabrian Mountains in Northern Spain extend the European continent about $500 \mathrm{~km}$ to the west in a succession of massifs aligned parallel to the coast. The marginal, southern continental position of these mountains induced

*E-mail: manuel.frochoso@unican.es

${ }^{\dagger}$ E-mail: raquel.gonzalez@unican.es

\#E-mail: fernando.allende@uam.es small glaciers to form in them during the Late Pleistocene. Our research is focused on a sector of the Central Cantabrian Mountains, the Asón Area of the Castro Valnera Massif.

Evidence of Pleistocene glaciation in the Cantabrian Mountains was recognized relatively early [1] but it was not until the twentieth century that systematic glaciation study began. Obermaier [2] distinguished two glaciations in the Picos de Europa and his scheme was repeated for the Cantabrian Mountains, e.g. [3-7], including Castro Valnera $(1718 \mathrm{~m})$ and the karstic Asón platform and sum- 

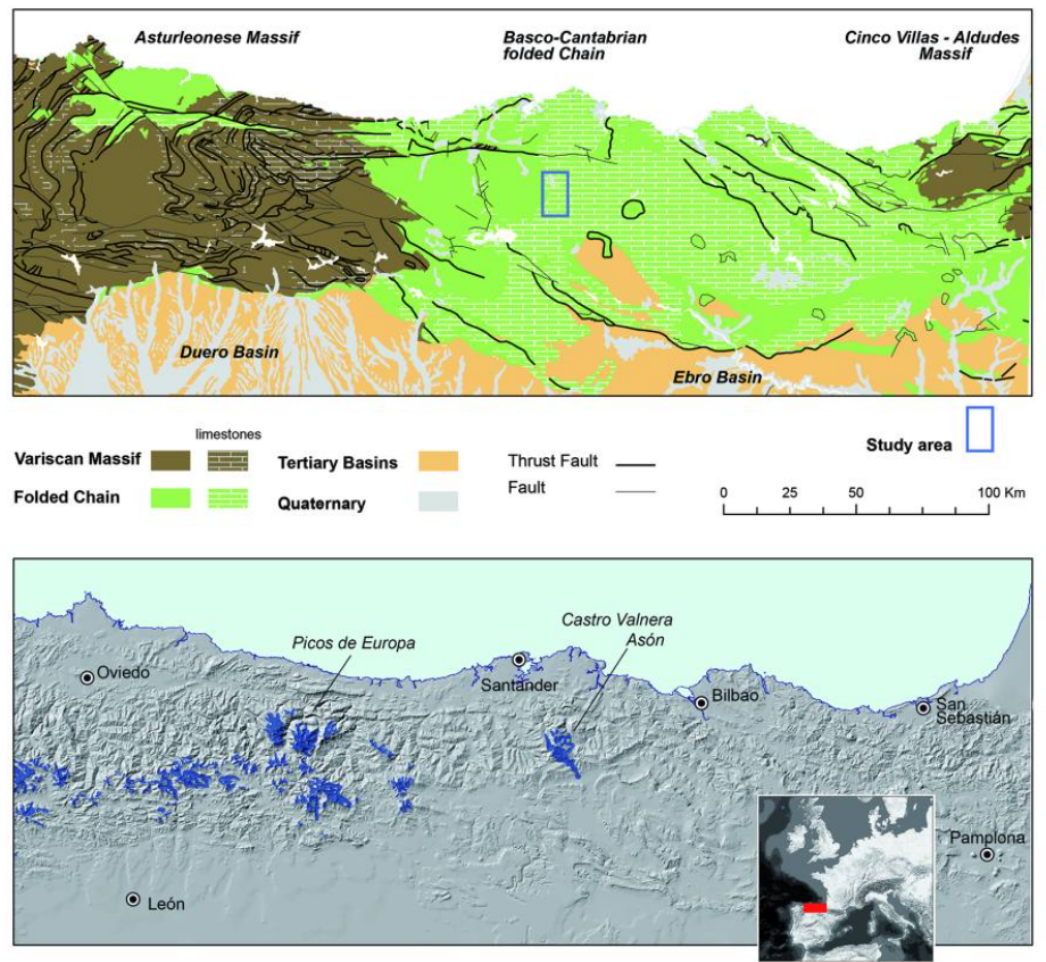

Figure 1. Geological sketch and representation of the maximum extent of mountain glaciers in the Cantabrian region (expanded and modified from Frochoso and Castañón, 1998).

mits $[8,9]$. The observations during the second half of the twentieth century were focused on discussing the limits and the effectiveness of the two glaciations, e.g. [10-20], which enabled the very precise delimitation of the area affected by the glaciers in the Cantabrian Mountains (Figure 1). The maximum glaciation identified in these areas did not extend beyond the strictly mountainous zones; the glacial tongues did not reach the foothills. Only in very rare cases, such as the Trueba glacier in the Valnera massif, did the glacial tongues extend into peripheral depressions.

The Cantabrian glaciation chronology and absolute ages have been the most recent focus of attention. The global Last Glacial Maximum (LGM) and the last local maximum in these mountains were thought to be synchronous, e.g. [21-23], but the chronological schemes changed when new age data became available for the maximum glacial development from the Pyrenees. Both on the northern slopes, e.g. [24-27] and on the southern side, e.g. [28-34], the ages obtained from different glacial-related deposits and surfaces provide evidence of a Pyrenean last glacial maximum prior to $30 \mathrm{ka} \mathrm{BP}$, although other age data also indicate its coincidence with the LGM [35]. The glaciation dates of the Cantabrian Mountains have also been obtained [36-39], including the southern slope of the Valnera Massif [40]. These age data indicate that the local last glacial maximum in the Cantabrian Mountains took place earlier than 35 ka BP.

New research has reviewed the glacial age data from Northern Spain and the Mediterranean mountains in a detailed manner, focusing either on a single massif, or on the whole system [41-46]. These studies provide growing evidence for the asynchronicity of their glacial maxima with respect to the maximum extent of the European Ice Sheet. Other more wide-scale studies have even suggested that it may be necessary to re-evaluate the concept of Last Glacial Maximum (LGM) as a simple global event [47].

The main aim of this paper is to contribute knowledge about the glacial geomorphological record in the Asón Mountains of the Valnera Massif, relating it to the features observed in the surrounding Iberian and Alpine mountains. The paper attempts to provide a detailed understanding 


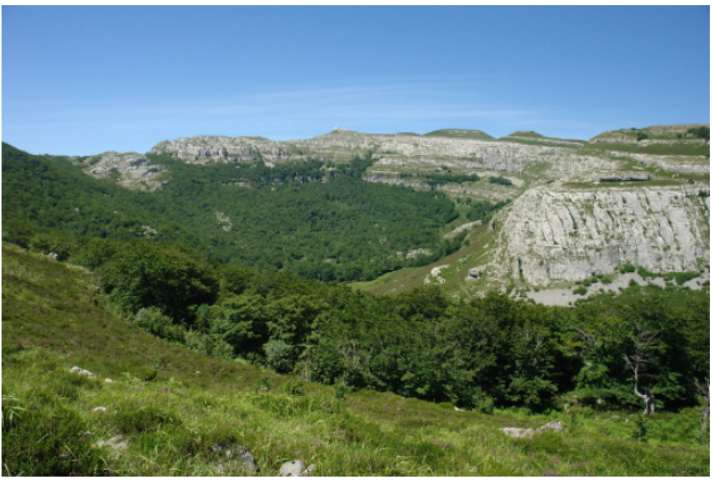

Figure 2. Low-inclined limestone platform of the Asón and its summit (Picón del Fraile, $1625 \mathrm{~m}$ ) and trough (BusturejoHondojón).

of the glacio-karstic geomorphology, focused on the Asón and Gándara valleys. Moreover, our research will try to determine the detailed position and age of glacial sediments and reconstruct the different glacial stages that occurred during the last maximum in the Asón platform. We will try to approximate the "last local glacial maximum (LLGM)", as it has been named previously [48], comparing its age with the age provided for other Spanish and European mountains.

The Valnera-Asón Mountains are a part of the BascoCantabrian system. The northern valleys, dominated by the Castro Valnera crests, have very steep fronts, while their backs fall gently to the Trueba valley of the Mediterranean Ebro network. The Eastern extension of the crests of Castro Valnera gradually transform into the inclined SSE limestone Asón platform (Figure 2). This plateau contrasts, further east, with the marly rocks of the Soba Valley, where the Gandara River flows.

Lotze $[8,9]$ inferred the existence of a large icefield on the soft backs of the southern slope of Castro Valnera, whose ice was eventually channelled to the south through the Trueba valley down to the Ebro Basin. Its termination in a small lobe at Espinosa de los Monteros $(760 \mathrm{~m})$ is well demonstrated by the arcuate moraine complex found there $[11,49,50]$. The Valnera icefield also overflowed through different passes to the heads of the Cantabrian valleys. This ice cap fed into the Miera valley to the north, creating a tongue reaching el Toral $(650 \mathrm{~m})[17,18]$. Moreover, to the NNE, the Asón ice cap (Figure 3) remained attached to it by diffluent passes (Canal_Busturejo, $1325 \mathrm{~m}$ and Tramasquera, $1375 \mathrm{~m}$ ) although it only contributed a relatively small ice flow [20]. The pre-glacial relief (structural low inclined platforms and many large karstic depressions) favoured snow accumulation in the Asón ice cap $[51,52]$.

The geomorphology and geochronology of glaciation dur-

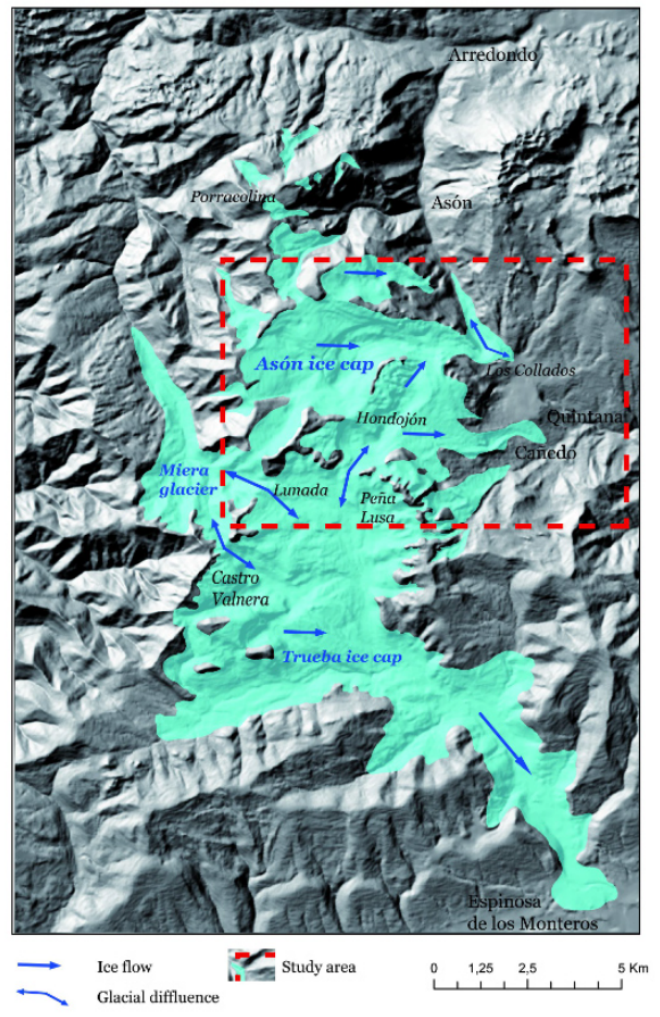

Figure 3. Reconstruction of maximum extent of glaciers in the Castro Valnera massif (modified and extended from Lotze, 1962), with indication of the study area.

ing the last cold stage in the Asón area is reviewed below. As has been confirmed in other studies [53], these glaciers were small compared to the glaciers in the Pyrenees or in the Alps, but their limited extent and southerly latitude, on the south-western boundary of Europe, made them especially sensitive to climate change. Their detailed study can facilitate the understanding of past cold periods.

\section{Materials and methods}

Two methodologies were followed in the work: geomorphological mapping and chronological study of glacialrelated sediments.

The characterization, the spatial distribution of landforms and deposits and the preparation of relativechronology sequences indicating glacial activity were recorded through geomorphological mapping of "Los Collados del Asón" Natural Park. First, we identified geomorphological features from the photo-interpretation of 
stereoscopic pairs (CETFA 1988) and orthophotos (5m resolution, SIGPAC 2003). Then we carried out a detailed field mapping of previously unrecorded or badly recorded landforms and deposits. These records were added into the general mapping system, designed in ArcGIS 9.x (partially shown in Figure 4). The features identified were grouped according to the morphogenetic system (glacial, karstic, running water, mass wasting). The identification and relative chronology of glacial landforms and deposits enabled a qualitative differentiation of several stages of glaciation during and after the local last maximum extent of glaciers.

The chronological study was done in the following steps. i) Selection of sites for collecting samples of significant sediments (diamicton from lateral and latero-frontal moraines made up of till) to later submit them to laboratories for absolute dating; ii) partial sedimentary analysis of some samples; iii) interpretation of absolute dating data.

We collected diamicton samples along with carbonated precipitation integrated within the fabric of the diamicton, and some deposits and soils that capped the till. These samples all came from lateral and latero-frontal moraines that indicated distinct phases of glaciation (Figure 5).

Sampling was done both manually and mechanically. In some cases, we collected samples by hand for sedimentary analysis (till and related deposits in Los Collados laterofrontal moraine) or absolute dating (U-Th) carried out in external laboratories (carbonates in cemented till from the Bucebrón latero-frontal moraine and in the Zucía frontal moraine). In the same way, samples were obtained from a buried palaeosol in Los Collados moraine for ${ }^{14} \mathrm{C}$ dating.

Sometimes, the sampling was hampered by the care necessary to avoid contaminating the samples for Optically Stimulated Luminescence (OSL) dating. Bulk samples were collected of coarse and fine grain-size particles, taken as far as possible from boulders. These samples were always collected in opaque tubes and wrapped in light-proof bags. One group of these samples of diamicton was obtained by hand from the lateral moraine of the Cañedo glacier (Soba1-1, Soba1-2, and Soba1-3). Using a core drill vehicle (from TRIAX SA), another group of subsurficial and deeper specimens was sampled, which was obtained by impact in order to avoid the heat produced by friction, provided that the particle-size characteristics of the material were suitable. These samples of deposits from Los Collados moraine (M.I.1, M.I.2, M.I.Alt, M.I.3) were obtained successively up to 9 metres deep.

The detailed sedimentary analysis, grain-size distribution of sands, was done in order to characterise the levels that, on first viewing, could be distinguished in the laterofrontal moraines of Los Collados and Cañedo-Quintana. The sand grain-size distribution was done in five sam- ples from the till and overlying deposits of Los Collados moraine from a sector where the road provided a transverse cut through the axis of it. Once the samples were dry, organic material was removed, determining the sandy grain size distribution by sieving. Their distribution enabled us to characterize the stratigraphic levels, their similitudes and differences and their origin.

Three absolute dating techniques were applied, depending on the characteristics of each sample. AMS ${ }^{14} \mathrm{C}$ dating was performed on the bulk of the buried paleosoil from Los Collados by the Centro Nacional de Aceleradores (Seville, Spain). The dates obtained were calibrated in $2 \sigma$ using the program CALIB 6.0 [54]. U/Th dating was carried out in the Laboratorio de datación de Física Aplicada I (University of Seville) on three samples of carbonated precipitations from the interior of the tills from Zucia and from Bucebrón. All of these had a high content of detritus and it was necessary to correct the results in accordance with contrasted methods [55]. As we were dealing with a secondary deposit, the aim of the dating was to provide a minimum age to complement dates provided by other methods.

Lastly, dating was also performed with samples of some tills from Los Collados fronto-lateral moraine and the Cañedo-Quintana lateral moraine. All these samples were anomalous-fading tested in Laboratory, from the OSL response (TL-DA-10 system) obtained in a second scan after 240 hours storage in darkness. The signal losses detected in samples were less than $1 \%$. The fine grain method [56] was chosen and we selected a $2-10 \mu \mathrm{m}$ polymineral fraction. The dose stored in each sample from the last solar bleaching process was evaluated by the additive dose procedure. Errors linked to estimated ages took into account systematic and statistical errors corresponding to OSL measurements and the calibrating processes of radioactive sources. The calculation of errors was done using two complementary methods $[57,58]$.

Recent papers on glacial OSL dating $[59,60]$ indicate that glacial sediments are often quickly deposited and perhaps do not undergo sufficient exposure to daylight to enable a complete resetting of the luminescence signal. Our samples come from latero-frontal dump moraines with dominant supraglacial and englacial transport, which have more potential for bleaching than subglacial till. Nevertheless, heterogeneous bleaching of the elements from the same sample can be interpreted erroneously, leading to an age overestimation. We tested these deposits with the purpose of verifying the importance of these effects on the resulting ages. First, we collected several luminescence samples from the same stratigraphic horizon in diamictons from different moraines (upper level of two latero-frontal dump moraines from Los Collados and Cañedo). The ages 


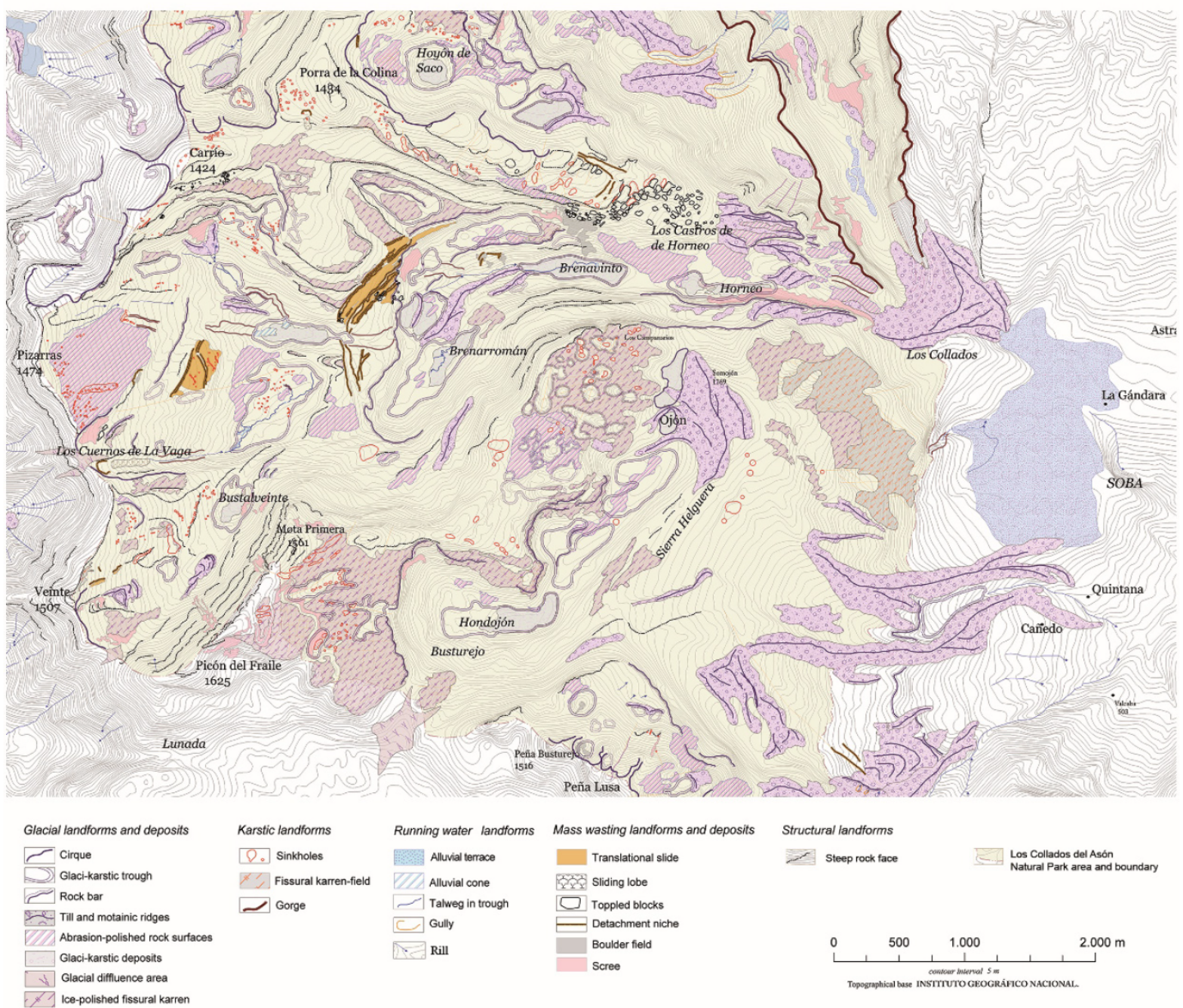

Figure 4. Geomorphological map of Los Collados delAsón Natural Park. The area depicted is highlighted in Figure 3.

obtained were all very close. Second, the age obtained in till samples from Los Collados and relative chronologies from stratigraphic level sequences provided coherent chronostratigraphic results. If differential bleaching had been significant in the samples, the probability of obtaining dates that were coherent with the sequence of relative chronologies would be very low.

\section{Results}

\subsection{Glacial landforms and related deposits}

The Valnera massif and the Asón platform display a diversity of glacial landforms whose complexity is due to karstification. The Asón massif and the head of the Trueba valley are karstic platforms, slightly tilted towards the $S$ and SE with large depressions (Hondojón, Bustalveinte, Brenavinto) where ice accumulated.

The landforms in these accumulation areas were predominantly sculpted by abrasion rather than plucking. Cirques are therefore scarce and poorly developed and their appearance is more due to the morphostructural conditions rather than effective plucking. The few cirques are located at the feet of the higher peaks (northern side of the Valnera, eastern foothills of Peña Lusa) where potential for overdeepening was increased by differential erosion. The troughs and sinkholes of mixed glacial plucking and karstic origin are hundreds of metres wide and deep, and are aligned according to the structural directions. Panels polished by glacial abrasion are frequent, especially 


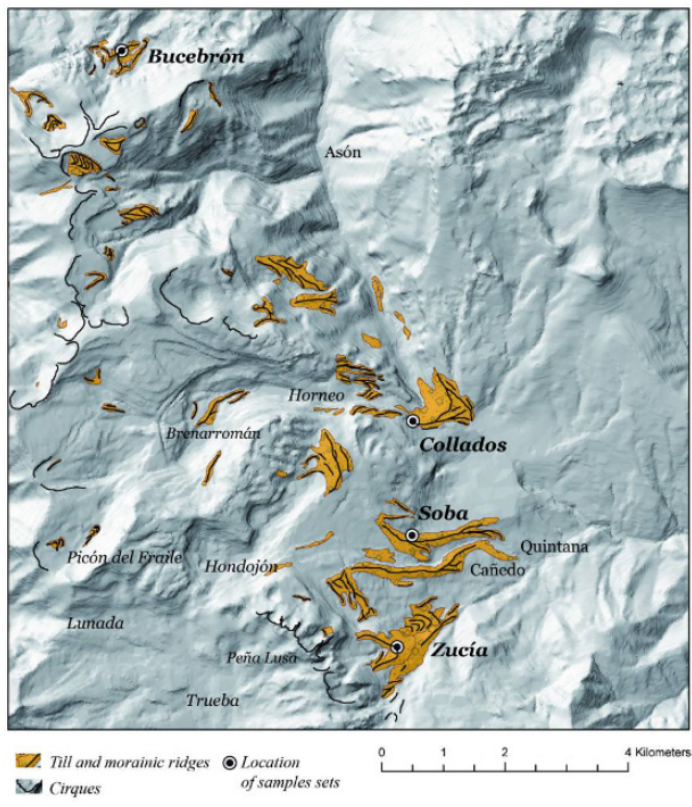

Figure 5. Localization of the deposits which contained samples used for absolute dating.

on the rock-bars between the glaci-karstic basins (Horneo and Hoyón de Saco). Moreover, there are wide fields of fissural karren, which have taken advantage of a dense network of vertical joints. This orthogonal network of fractures affecting the limestone platform has also facilitated quarrying, and explains the plucking troughs aligned there (SW-NE, Bustalveinte, 1170 m, Brenarromán, 920 m, and W-E, Brenavinto, 855 m, Horneo, 848 m, in its central area, and also SW-NE, Busturejo-Hondojón, $1041 \mathrm{~m}$, Ojon, $1023 \mathrm{~m}$, in its southern sector).

Varied groups of till and related deposits are widespread on the Asón platform and its edges. Some of these form complex morainic ridges at the edge of the massif; Cañedo-Quintana lateral moraines with four welldeveloped branches between $1050 \mathrm{~m}$ and $600 \mathrm{~m}$; the latero-frontal moraines of Los Collados (690 m), a complex set of moraine strings, which indicate at least five glacial re-advances or, perhaps, periods of dynamic equilibrium during glacial recession; the till deposited at the bottom of the Asón gorge $(300 \mathrm{~m})$; the satellite massifs in the north of the platform (Porracolina-Bucebrón and Hoyón de Saco) and in the south of it (Peña Lusa) also contain their own moraine fields with well-defined moraine ridges. Some form moraine complexes in the internal area of the platform; the ones surrounding the Hondojón, Horneo and Brenavinto troughs are clearly identifiable, displaying numerous parallel moraine ridges, while others

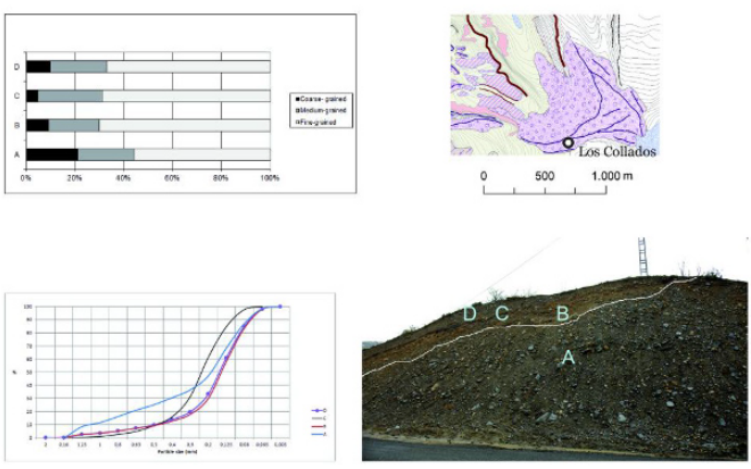

Figure 6. Los Collados fronto-lateral moraine. Particle-size distribution of the sandy part of the different levels of the deposit.

cover the bottom of the troughs.

The moraine complexes of the external area are often composed of massive light grey diamictons (5YR/7/1), among which, clast-supported boulders and cobbles are abundant, which were often cemented by carbonates. Above this massive diamicton, the moraine is topped with several metres of materials in which a fine matrix is abundant, displaying a different colour, light yellowish brown (10YR/6/4), and moreover, without carbonated cementations. These sedimentary levels are, in turn, capped by a thin layer of blackish soil.

We analysed the deposits of the latero-frontal dump moraine of Los Collados, which showed greater complexity and longer evolution. First, the deepest level (Level A) grey and slightly cemented has a lithofacies [61] of clastsupported massive diamicton with sandy to silt matrix $\left[\mathrm{DmM}(\mathrm{c})_{4}\right]$. Then there is another less thick layer (1 to $1.5 \mathrm{~m})$, Level $B$, with an abundant ochre- coloured fine matrix without cement $\left[\operatorname{DmF}\left(m_{1}\right)_{1}\right]$. However, there are two new partially overlapping layers: one thin $(10$ to $40 \mathrm{~cm})$, free of coarse material and very dark (Level C) and another more than 1 metre thick (Level D) with a lot of brown sandy clay $\left[\operatorname{DmF}\left(m_{1}\right)_{1}\right]$, before being finally crowned by the soil surface.

The lower level (A) is distinguishable from the higher ones in particle size and in the sandy matrix with abundant larger elements. The upper levels (B, C and D) have partly sorted material, predominantly fine particles and are less thick, especially at level C (Figure 6).

In the lower body (Level A) where the deposits are compact, the massive diamicton was deposited by cohesive debris flow formed by the gravitational flow of sedimentwater mixtures in this marginal glacial environment. The considerable thickness and poor sorting suggest short range of transport and deposition, perhaps due to "freezing". 
The overlying materials of Level B are also debris flow deposits, but diamictons, perhaps previously deposited within the periodically existing ponds in this marginal glacial environment. Here the role of water in transport was significant. It is a deposit characterized by rudites, with no distinct structure, which are loose and were deposited during glacial melting.

Level $C$ is very rich in organic matter and sporadically includes small fragments identified as Quercus robur charcoal. The level is clearly postglacial, originating at a time when an oak forest occupied the moraine, which in turn, was affected by fires. Level D corresponds to material deposited by a subsurficial slip from the top of the moraine which buried the existing soil (Level C).

\subsection{The Local Last Glacial Maximum (LLGM) and its deglaciation phases}

The position of the different moraine ridges and the spatial distribution of recognizably glacial formations have enabled us to reconstruct the extension of the local glacial maximum and the successive phases of deglaciation in these mountains. The most extensive ice caps formed there (Trueba, $56 \mathrm{~km}^{2}$; Asón massif, $33 \mathrm{~km}^{2}$ ) flowed over the accumulation area without a channelized direction, filling most of the relief, given that there were only a few isolated ridges and peaks.

During the Asón LLGM, an extensive ice cap fed two main tongues, the Soba ice-tongue and the Asón gorge icetongue. The maximum length and volume of ice was large enough to clog the valleys and troughs overflowing from the lower dividing alignments. In Busturejo-Hondojón the volume of ice was at least 150-200 metres thick, enough to exceed the height of the right lateral margin (Sierra de Helguera, $1130 \mathrm{~m}$ ), causing the diffluent Soba icetongue to the east, which formed the lateral moraines of Cañedo and Quintana $(500 \mathrm{~m})$. The main northerly flow descended by a cascade of seracs to the Horneo trough (848 m) meeting the major ice flows coming from the Asón platform. This second tongue was situated at the edge of the Asón gorge, falling to the valley bottom by a serac cascade. The ice filled the dead end of the head of the Asón up to the current height of Los Collados, where it left a series of latero-frontal moraines which form a small diffluent lobe to the south while the main flow went north. The lobe formed a complex set of moraine strings, which indicate at least five glacial re-advances or, perhaps, periods of dynamic equilibrium during glacial recession. Once the ice became trapped in the gorge, its advance northward and down the valley caused a reduction in its thickness, forming a highly bevelled front at $300 \mathrm{~m}$ altitude, one of the lowest recognizable altitudes of glaciation in the Iberian Peninsula.

After the LLGM, a new shorter glacial advance left less bulky moraines in the internal troughs of the Asón platform. These moraines indicate different stages of progression of less developed tongues of only a few kilometres in length (Figure 7). The tongues did not meet, as they had done during the LLGM, defining the Tongue Disjunction Phase (TDP) with two episodes, the most advanced one (TDP_1) reached Horneo (northern tongue) and Somojón (southern tongue) and the less advanced (TDP_2) reached Brenarromán and Hondojón (Figure 8). Finally, there are some moraines in surrounding positions that are very close to the highest points of the platform, such as in Bustalveinte, indicating the presence of a Residual Ice Phase (RIP) in this massif.

The period of deglaciation between the various phases of glacial advance (LLGM, TDP 1 and 2, RIP) also produced a series of paraglacial readjustments [62-64]. Paraglacial dynamics was favoured by alternating lithology in which the limestones, with a dense and orthogonal network of joints, lay over sandstones and siltstones. When the iceinduced pressure on the bed disappeared, some steep edges of glacial troughs collapsed under the sliding of the limestone rock mass (Figure 9). In some cases, translational and rotational slides caused by decompression produced long linear scars (one or two kilometres long) and narrow passages that form lines across the valley. In other cases, cubic elements form disjointed blocks whose movement also often involved a rotational component (Castros de Horneo).

\subsection{Absolute dating of Local Last Glaciation Maximum}

Judging by the dating of Los Collados morainic diamictons, the LLGM was a long-lasting glacial phase. The sequence obtained (Table 1) from the core dating by OSL of Los Collados deposits starting from $9.5 \mathrm{~m}$ depth, shows a continuous deposit from at least $78.54 \pm 7.1 \mathrm{ka}$ to $40.42 \pm 5.1 \mathrm{ka}$, with intermediate dating at $6.5 \mathrm{~m}(75.05 \pm 5.91 \mathrm{ka})$ and $5.3 \mathrm{~m}(64.59 \pm 5.07 \mathrm{ka})$ depth.

Although the core of the glacial related deposits apparently displays an uninterrupted vertical sequence, the glacier underwent advances and retreats during a long period. During this long period, it is possible that there were five small glacial pulses in Los Collados, which can be deduced from the diffluent branching of these moraines. As the diamicton samples were taken in the common part of the moraine, from above the diffluent lobe, we can hypothesize that these branches were formed during glacial pulses which occurred between at least $78.54 \mathrm{ka}$ and $64.59 \mathrm{ka}$. All these ages are included in level A of Los 

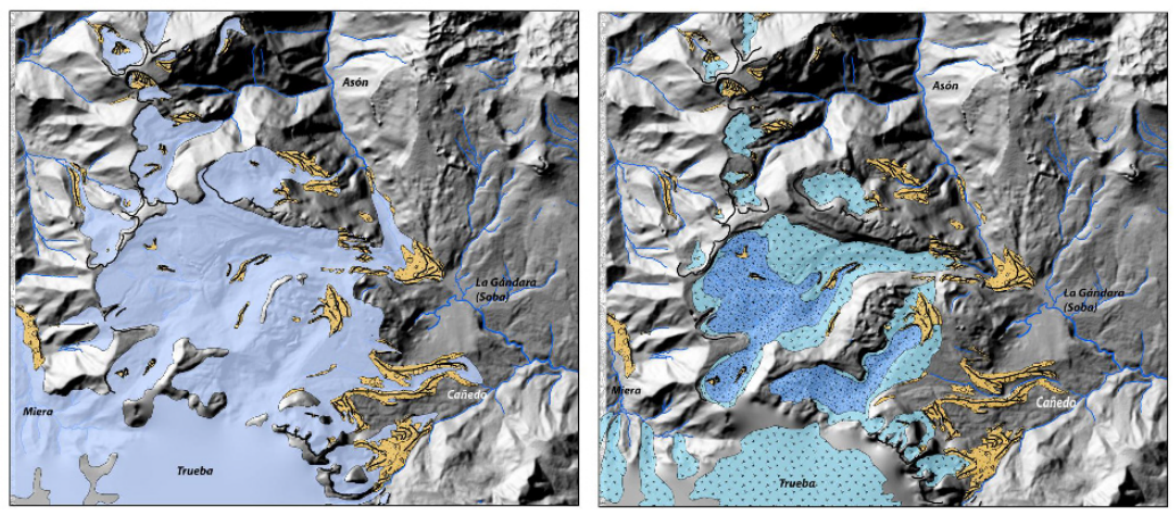

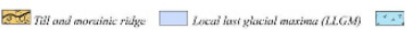

0.5

Figure 7. Sketch of the ice extent in the Asón area during the distinct glacial phases. Left, glaciers and moraines from the last local glacial maxima. Right, glaciers from the two stages of the tongue disjunction phase.

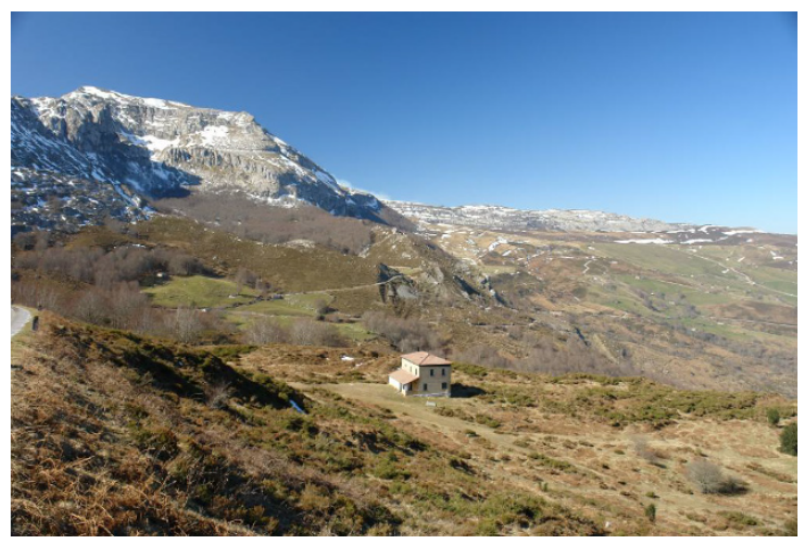

Figure 8. Glacial morphology in Peña Lusa with its arcuate moraine of TDP_1.

Collados deposits. Afterwards, between 64.59 ka (Level A) and 40.42 ka (Level B), there was a stratigraphical and chronological variation which is coincident with the last episodes of this glacial margin.

These facts are also consistent with the dates obtained in the outermost lateral diffluent moraine of Cañedo, where samples (Soba 1-1, 1-2, 1-3) belonging to the local highest layer (level B) provided an age consistent with the same layer in Los Collados (from $44.97 \mathrm{ka}$ to $41.56 \mathrm{ka}$ ), within a margin of error. It seems that the transition from a regime with an active glacier to a sparsely active glacier was very quick (between $45 \mathrm{ka}$ and $40 \mathrm{ka}$ ), which contrasts with such a long LLGM (from 78 ka up to 45 ka with continued deposits).

The dates obtained from the carbonated precipitations through the OSL dating and U/Th dating methods show a great disparity. As these are secondary precipitations in

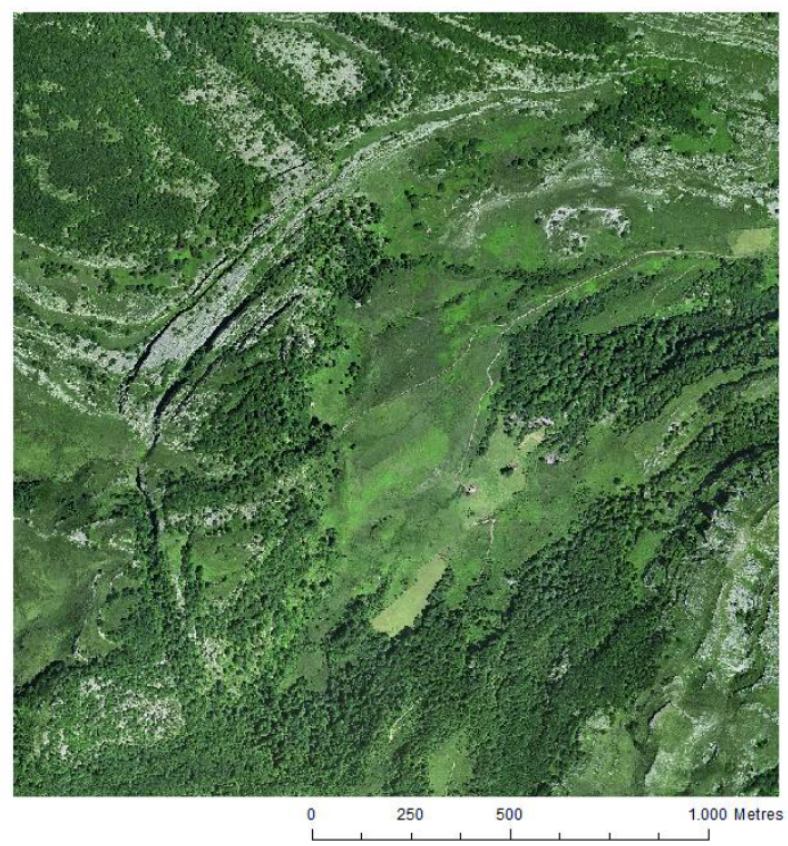

Figure 9. Paraglacial translational slides in Brenarromán. Aerial view from orthophoto of SIGPAC, 2003.

the interior of the till, they have only provided minimum ages for the primary deposit and they can only indicate phases in which the carbonated precipitation was accentuated. They do not prove useful in dating the distinct glacial phases and episodes.

Likewise, the buried soil overlying the till of Los Collados does not identify glacial phases although it may indicate that Los Collados moraine was covered by an oak forest between 1,981 and 1,771 cal BC. 
Table 1. Absolute Dating of the distinct Asón deposits.

Laboratory of Radiochemistry Dating at the Autonomous University of Madrid (OSL), Laboratorio de datación de Física Aplicada I, University of Seville (U/Th) and National Accelerator Centre (CNA) funded by CSIC and University of Seville $\left({ }^{14} \mathrm{C}\right)$

\begin{tabular}{|c|c|c|c|c|c|c|c|}
\hline Samples & Id $L a b$ & Material & Deposit & Depth & $\begin{array}{c}\text { Age } \\
\text { OSL yrBP }\end{array}$ & $\begin{array}{c}\text { Age } \\
\text { U/Th yr BP } \\
\text { cal } 2 \sigma B C \\
\end{array}$ & $\begin{array}{c}\text { Age } \\
{ }^{14} \mathrm{C} \text { yr BP / }\end{array}$ \\
\hline Zucia M-1 & MAD-5893rSDA & $\begin{array}{l}\text { Secondary } \\
\text { Carbonates }\end{array}$ & $\begin{array}{c}\text { Breccia in } \\
\text { Zucia moraine }\end{array}$ & $\begin{array}{c}0.5 \mathrm{~m} \\
\text { subsurficial }\end{array}$ & $13,419 \pm 1,246$ & & \\
\hline Zucía M-2 & SEV-ZUC & $\begin{array}{l}\text { Secondary } \\
\text { Carbonates }\end{array}$ & $\begin{array}{c}\text { Breccia in } \\
\text { Zucia moraine }\end{array}$ & $\begin{array}{c}0.5 \mathrm{~m} \\
\text { subsurficial }\end{array}$ & & $6,282 \pm 571$ & \\
\hline Soba1-1 & MAD-5498rBIN & $\begin{array}{l}\text { Fine silt } \\
\text { and clay }\end{array}$ & $\begin{array}{c}\text { Diamicton from } \\
\text { Cañedo-Quintana } \\
\text { moraine }\end{array}$ & $3 \mathrm{~m}$ & $41,559 \pm 2,397$ & & \\
\hline Soba1-2 & MAD-5499rBIN & $\begin{array}{l}\text { Fine silt } \\
\text { and clay }\end{array}$ & $\begin{array}{c}\text { Diamicton from } \\
\text { Cañedo-Quintana } \\
\text { moraine }\end{array}$ & $3.5 \mathrm{~m}$ & $44,978 \pm 2,365$ & & \\
\hline Soba1-3 & MAD-5514BIN & $\begin{array}{l}\text { Fine silt } \\
\text { and clay }\end{array}$ & $\begin{array}{c}\text { Diamicton from } \\
\text { Cañedo-Quintana } \\
\text { moraine }\end{array}$ & $3 \mathrm{~m}$ & $44,530 \pm 2,448$ & & \\
\hline M.I.1 & MAD-5677BIN & $\begin{array}{l}\text { Fine silt } \\
\text { and clay }\end{array}$ & $\begin{array}{c}\text { Diamicton from } \\
\text { Cañedo-Quintana } \\
\text { moraine }\end{array}$ & $2.5 \mathrm{~m}$ & $40,426 \pm 5,144$ & & \\
\hline M.I.2 & MAD-5678BIN & $\begin{array}{l}\text { Fine silt } \\
\text { and clay }\end{array}$ & $\begin{array}{c}\text { Diamicton from } \\
\text { Cañedo-Quintana } \\
\text { moraine }\end{array}$ & $5 m$ & $64,592 \pm 5,071$ & & \\
\hline M.I.Alt & MAD-5680BIN & $\begin{array}{l}\text { Fine silt } \\
\text { and clay }\end{array}$ & $\begin{array}{c}\text { Diamicton from } \\
\text { Cañedo-Quintana } \\
\text { moraine }\end{array}$ & $6.5 \mathrm{~m}$ & $75,055 \pm 5,196$ & & \\
\hline M.I.3 & MAD-5679BIN & $\begin{array}{l}\text { Fine silt } \\
\text { and clay }\end{array}$ & $\begin{array}{c}\text { Diamicton from } \\
\text { Cañedo-Quintana } \\
\text { moraine }\end{array}$ & $9.5 \mathrm{~m}$ & $78,540 \pm 7,159$ & & \\
\hline Colason1_1 & CNA506 & $\begin{array}{l}\text { Organic } \\
\text { matter }\end{array}$ & $\begin{array}{c}\text { Paleosoil overlying } \\
\text { till of Los Collados } \\
\text { moraine }\end{array}$ & $2 m$ & & & $\begin{array}{c}3,555 \pm 40 \text { BP } \\
1,981 / 1,771 \mathrm{cal} \mathrm{BC}\end{array}$ \\
\hline BU.2 & SEV-BUC2Inf & $\begin{array}{l}\text { Secondary } \\
\text { Carbonates }\end{array}$ & $\begin{array}{c}\text { Breccia in } \\
\text { Bucebrón moraine }\end{array}$ & $3.5 \mathrm{~m}$ & & $7,088 \pm 942$ & \\
\hline BU.1 & SEV-BUC1 & $\begin{array}{l}\text { Secondary } \\
\text { Carbonates }\end{array}$ & $\begin{array}{c}\text { Breccia in } \\
\text { Bucebrón moraine }\end{array}$ & $4.5 \mathrm{~m}$ & & $4,267 \pm 129$ & \\
\hline
\end{tabular}

\section{Discussion}

\subsection{The LLGM in the Asón Mountains: com- parison with other areas of Europe and $\mathrm{N}$ Iberian Peninsula}

Some authors $[44,46,53]$ have suggested that the differences observed between the age of the LGM and LLGM may be associated with dating techniques and the possible inclusion of dating errors. In this work, the ages obtained from the tills through OSL dating using large multigrain aliquots could present the problem of the ages being overestimated due to incomplete bleaching of sediments at deposition, as has been suggested on some occasions $[65,66]$. We have taken into account the observations of some authors $[67,68]$ who highlighted, after analysing a large number of samples using the same procedure as we used, that for relatively old samples, greater than $50 \mathrm{ka}$, the importance of incomplete bleaching is likely to be limited. Moreover, they deduced that incomplete bleaching is more significant for younger samples. Although our samples may have a degree of error lead- 
ing to an overestimated age, as they are old, this error is likely to be relatively small. We also found internal chronostratigraphic consistency within the data following a procedure recommended by some authors [59]. We collected a part of the samples from the same stratigraphic horizon (transition Level A to Level B in till of Cañedo) in different deposits (similar level transition in till of Los Collados). The coincidence in the ages obtained, consistent with the margins of error inherent to the method, enabled us to further verify the reliability of the working procedure. Finally, recent discussions about glacial chronologies in northern Spain [44] based on several dating techniques also support our results. Among these, many of the revised ${ }^{14} \mathrm{C}$ AMS and OSL chronologies are congruent with some scenarios of glacial evolution $[53,69]$ which propose the asynchronicity of global glacial maximum and those of different mountain regions.

In view of our results, the occupation of these valleys by glaciers during the phase of maximum ice (LLGM) is chronologically well centred on the period of ice build-up recorded by the SPECMAP curve between 75 and $65 \mathrm{ka}$ BP (MIS 4). It extends towards older, short and cold substages (MIS 5b), and to other more recent stages shown in that reference curve (MIS 3d). We were not able to date the beginning of the local maximum glacial stage (LLGM) but we can place it during Early Würm, according to the chronology of alpine glaciation proposed previously [70]. We think that this peculiar development of glaciers here may be due not only to cooling but also to an increase in precipitation. The increased moisture in the north of the Iberian Peninsula has also been revealed by comparative studies of lacustrine deposits [71], palynological data [72] and marine deposits [73]. In addition, locally, from the inequality and greater range of glaciers we can deduce that there was an increased abundance of snow precipitation in the Valnera-Asón massif with respect to the surrounding Cantabrian and Pyrenean mountains.

The early onset of the LLGM with respect to the LGM has already been highlighted on several occasions recently $[46,47,53,70]$. In the eastern Alps, the glaciers did not reach the main alpine valleys during Early Würm although they were occupied by ice later, as described for the Tyrol [74], and the ice-free Inn Valley from MIS 5c to 5a [75]. However, in the Western Alps, it is considered that there was extensive glaciation that reached the foothills during MIS 4 and MIS 5d [76], although this did not exceed the limits of later glaciation (MIS 2). Nevertheless, it has also been considered for the French Alps that the maximum extent of glaciers occurred during MIS 4 and not during MIS 2 [77]. Similar results were provided for the southernmost mountains. To the south of the Mediterranean [78], in the High Atlas, an early glaciation was dated around $76.0 \mathrm{ka}$, while in the Central Iberian System [79, 80], the oldest ages were between 31 and 26 ka.

However, the results obtained for the glaciation of the Pyrenean and Cantabrian Mountains offer fewer doubts. A local maximum (LLGM) prior to the global maximum (LGM) was corroborated, detailed and dated [27, 34, 41, 8189]. However, other results have also been obtained in the Noguera Ribagorzana Valley $[35,90]$. They indicate that the Pyrenean maximum may have been synchronous with the LGM; placing the formation of its most-advanced moraines at 25 ka BP, suggesting a long Pleniglacial period between 30 and $20 \mathrm{ka}$ BP.

Similarly ice-dammed lacustrine deposits were dated in the Cantabrian Mountains [43, 91, 92] using radiocarbon dating establishing their age at earlier than $35{ }^{14} \mathrm{C}$ ka $\mathrm{BP}$, very close to the fluvioglacial filling of the Comeya depression, dated at $40.38{ }^{14} \mathrm{C}$ ka BP $[36,37]$, and Campo Mayor, dated prior to 35.7-34.8 cal BP [39] both in the Picos de Europa. Moreover, the lacustrine deposits filling the over-deepened trough at the end of the Enol Glacier in the Picos de Europa, provide dates that place the glacial maximum [38] prior to $38{ }^{14} \mathrm{C}$ ka BP, although absolute dates have not been obtained for all the glacial deposits. In any case, in Los Collados moraines the continuity of sedimentation of till from at least $78 \mathrm{ka}$ (M.I.3, M.I.Alt) to after $65 \mathrm{ka}$ (M.I.2) places the timing of glaciation as synchronous to the glaciation described previously [46], close to the transition from MIS 5 to MIS 4, probably from MIS $5 \mathrm{~b}$. It also indicates the persistence of an active glacier in which different pulses perhaps formed the frontal moraines at the diffluence from Los Collados towards Soba. Subsequently, the erosive efficacy of glaciers gradually decreased there and between $45 \mathrm{ka}$ and 40 ka (Soba 1-1, Soba 1-2, Soba 1-3 and M.I.1) the deposition of ablation tills started, characterized by rudites, now fully integrated in MIS 3.

\subsection{Deglaciation after Local Glacial Maxi- mum in the study area}

The glacial retreat in the Asón Valley coincided with some notable events in nearby archaeological sites. Among them, there was continuous human occupation since more than 35 ka BP in El Mirón Cave in the lower Asón Valley [93], which corresponds well with the milder climate. The magnetic susceptibility of this cave's sediments, related to other Iberian archaeological sites [94, 95], shows that there was a relatively mild period between $43 \mathrm{ka}$ and $37.5 \mathrm{ka}$. This period coincides with the end of the age of active glaciers in the Asón massif. There are many parallels between the glacial retreat and the Heinrich 4 
event [96], which has also been identified as an abrupt fluctuation in the Iberian climate during MIS $3[97,98]$. Recent papers [46] suggest that during MIS3 the Iberian mountain glaciers may have undergone a rapid retreat caused by warm events associated with D-O cycles (e.g. interstades 8 and 12 dated at $37 \mathrm{ka}$ and $45 \mathrm{ka}$ BP respectively). This did not take place in the alpine mountain glaciers or in the Scandinavian ice sheet where glaciers continued to grow or remained stable due to their greater inertia. These events indicate drier conditions in Iberian mountains during MIS3 than during MIS4 and MIS2 [71]. In the Asón platform, the low altitudes, southern position and slight variations in temperature and humidity may explain the rapid growth or, conversely, decline and retreat of the glaciers.

A new glacial advance, Tongue Disjunction Phase (TDP), shorter than the LLGM, occurred in the Asón platform. According to the ages obtained for the moraines of the LLGM, we suggest that the development of this new phase coincided with the LGM within MIS 2, which has been described in the European mountains between 30 and 18 ka $[53,70]$. In the Pyrenees, this glacial advance was also noted $[46,83]$, indicating a cold stage at around $20 \mathrm{ka}[85,90]$. This cold period is also indicated by the magnetic susceptibility of sediments [95] near the Asón platform, which showed a cold phase that began about $27 \mathrm{ka}$ BP and ended in the coldest stage around $20.5 \mathrm{ka}$ and $17.5 \mathrm{ka}$ BP. This probably fits with the two previously described glacier substages corresponding to the beginning of the cooling $c a$. 27-25 ka BP (TDP1), followed by a retreat and an advance that built up the higher moraines (TDP 2), between ca. 21-18 ka BP.

It is likely that after the TDP, the glaciers disappeared from the Asón platform. Further cooling only produced a small number of little glaciers indicating a Residual Ice Phase (RIP). In the Pyrenees and the Alps, a similar stage of glaciation has been reported, e.g. [99], with fluctuations of alpine glaciers during the Pleistocene to Holocene transition. In any case, in these mountains this cooling may have occurred at an undetermined time during the Late-Glacial phase (between 14.5-10 ka).

\section{Conclusions}

The Asón platform and peaks present a peculiar complex of glacial landforms and deposits derived from the southern position and proximity to the Atlantic, on the edge of the Pleistocene glaciation area. Due to this marginal position, the area is very sensitive to climatic changes. Furthermore, the Valnera-Asón massif received more precipitation at a lower altitude than other nearby Cantabrian
Mountains. Thus, the Asón ice cap emitted tongues whose fronts were the lowest in the Iberian Peninsula (300 m). The glacial related deposits of the LLGM in Los Collados were dated by OSL at between $78.5 \mathrm{ka}$ and $40 \mathrm{ka}$. However, the prospection did not reach the bottom of the till formation and we suppose that the LLGM started either during MIS $5 \mathrm{~b}$ or in the transition from MIS 5 to MIS 4. The LLGM development is centred during MIS 4 and even extends to MIS 3. However, it ends abruptly as is shown by the higher levels of the morainic diamictons. The upper levels provide similar ages in Los Collados and Cañedo tills, from distinct tongues, ranging between 44.9 and $40.4 \mathrm{ka}$.

The tills located higher up (850-1050 m) reflect a new glacial phase (TDP) with two well-defined events that can be dated during MIS 2, during the LGM. After these episodes the glaciers disappeared from the Asón Mountains and only some residual glaciers (RIP) were formed that may be related to the Late-Glacial.

During these cold episodes, with glacial retreat and the subsequent decompression of the bedrock, a paraglacial dynamic led to rotational and translational landslides.

Finally, during the Holocene, the plant covered moraines were affected by fire in Los Collados $\left(3.5{ }^{14} \mathrm{C}\right.$ ka BP), leaving a very well-defined horizon of fragments of Quercus robur charcoal that were later buried and preserved as a palaeosol.

\section{Acknowledgements}

The authors are grateful to the Ministry for Rural Development, Agriculture, Fisheries and Biodiversity of the Cantabrian Regional Government for providing us with support and the field assistance of guides and rangers from "Los Collados del Asón" Natural Park. The authors would like to thank the editor and anonymous reviewers for their comments and suggestions that helped to improve the manuscript. We are also grateful to Dermot Erskine for his help in the English revision of the text.

\section{References}

[1] Prado C. de, Note sur les blocs erratiques de la Chaine Cantabrique. [Note about erratic boulders of the Cantabrian Mountains] Bull. Soc. Geol. France, Séance du 2 Février 1852, 171-175 (in French)

[2] Obermaier H., Estudio de los glaciares de los Picos de Europa. [Research about the glaciers of the Picos de Europa] Trab. Mus. Nac. Cien.Nat., Serie geológica, 1914, 9, 42 p (in Spanish) 
[3] Stickel R., Observaciones de morfología glaciar en el NO de España. [Notes about Glacial morphology in NW Spain] Bol. Real.Soc.Esp. Hist. Nat., 1929, XXIX, 297-313 (in Spanish)

[4] Sáenz C., Restos glaciares de Castro Valnera. [Glacial remains in Castro Valnera] Bol. Real Soc. Esp. Hist. Nat., 1935, 236-237 (in Spanish)

[5] Hernández Pacheco F., Fisiografía, geología y Glaciarismo cuaternario en las Montañas de Reinosa. [Physiography, geology and Quaternary glaciation in the mountains of Reinosa]. Mem. Real Acad. Cien., 1944. 1-190 (in Spanish)

[6] Nussbaum F., Gygax F., La Glaciación Cuaternaria en la Cordillera Cantábrica. [Quaternary glaciation in Cantabrian Mountains] Estudios Geográficos, 1953, 51, 261-270 (in Spanish)

[7] Hernandez Pacheco F., La pequeña cuenca glaciar de la Peña de Lusa en la Cordillera Cantábrica, Santander. [The small glacier basin of the Peña Lusa in the Cantabrian mountains, Santander] Bol. Real Soc. Esp. Hist. Nat., Sec. Geológica, 1961, 59-2, 191205 (in Spanish)

[8] Lotze F., Pleistozäne Vergletscherungen im Ostteil des Kantabrischen Gebirges (Spanien) [The Pleistocene Glaciation in Cantabrian Mountains (Spain)] Ab. Mathem.-Natur. Klasse. Mainz, 1962, 2, 1-27 (in German)

[9] Lotze F., Acerca de unas glaciaciones pleistocenas en el Grupo del Valnera (Cadenas Cantábricas orientales) [About Pleistocene glaciations in Valnera Group (Eastern Cantabrian mountains)] Not. Com. I.G.M.E., 1963, 72, 257-262 (in Spanish)

[10] Hazera J., Formaciones subáridas de piedemonte del surco de Espinosa (Cuenca superior del Ebro). [Foothills sub-arid formations in the depression of Espinosa (upper basin of the Ebro)]. Estudios Geográficos, 1962, 443-453 (in Spanish)

[11] Hazera J., La región de Bilbao et son arrière-pays: étude géomorphologique. [The Bilbao region and its foreland: Geomorphological resarch] Munibe. 1968, 20, 358 p (in French)

[12] Martínez de Pisón E., Arenillas M., Algunos problemas de morfología glaciar en la España Atlántica [Some problems of glacial morphology in the Atlantic Spain] Acta Geol. Hisp., 1979, 445-450 (in Spanish)

[13] Muñoz J., Morfología estructural y glaciarismo en la Cordillera Cantábrica: el relieve del Sinclinal de Saliencia (Asturias-León) [Structural and glacial morphology in the Cantabrian Mountains: The relief of Saliencia Syncline (Asturias-León)], Ería, 1980, 1, 35-67 (in Spanish)

[14] Alonso F., Arenillas M., Sáenz C., La morfología glaciar en las montañas de Castilla la Vieja y León, [Glacial morphology of the Castilla la Vieja and León mountains]. In: Proceedings of 1st Congreso de Geografía de Castilla la Vieja y León, Burgos, Spain. 1981, 23-43 (in Spanish)

[15] Frochoso M., El Macizo Central de los Picos de Europa y sus glaciares [The Picos de Europa Central Massif and its glaciers] Ería, 1980, 1, 67-87 (in Spanish)

[16] Castañón J.C., El glaciarismo cuaternario en el macizo de Ubiña (Asturias-León) y su importancia morfológica. [Quaternary glacial morphology in the Ubiña Massif]. Ería, 1983, 4, 3-49 (in Spanish)

[17] Martínez de Pisón E., Arenillas M., Nuevos problemas de morfología glaciar en la España Atlántica [New problems of glacial morphology in the Atlantic Spain]. Estudios Geográficos., 1984, 175, 159-174 (in Spanish)

[18] Moñino M., Cendrero A., Díaz de Terán J.R., Glaciarismo en el Alto Miera [The glaciation of the Alto Miera valley] In: Proceedings of the VII Reunión sobre el Cuaternario. AEQUA, Santander, 1987, 178180 (in Spanish)

[19] Castañón J.C., Glacial landforms in the Eastern and Central Asturian Massif, Ph.D. thesis, University of Oviedo, Spain, 1989 (in Spanish)

[20] Frochoso M., Castañón J.C., El relieve glaciar de la Cordillera Cantábrica [Glacial landforms of the Cantabrian Mountains]. In: Gómez A., Pérez A. (Eds.) Las huellas glaciares de las montañas españolas. Serv. Publ. University of Santiago de Compostela, 1998, 65-137 (in Spanish)

[21] Daveau S., La glaciation de la Serra da Estrela [The Serra da Estrela Glaciation], Finisterra, 1971, VII-11, 5-40 (in Portuguese)

[22] Tricart J, Pérez-Alberti A. Importancia e impacto del frío durante el Cuaternario [The significance and the impact of the cold during Quaternary] In: Proceedings of the International meeting "Otero Pedrayo y la Geografía de Galicia”. Santiago de Compostela, 1989, 74-91 (in Spanish)

[23] Pérez-Alberti A., Rodríguez-Guitian M., Valcarcel M. El modelado glaciar en la vertiente oriental de la Sierra de los Ancares (NW de la península Ibérica). [Glacial landforms in Eastern slopes of the Sierra de los Ancares (NW Iberian Peninsula)] Papeles de Geografía, 1992, 18, 39-51 (in Spanish)

[24] Mardonès M., Le Pléistocène superior et l'Holocène du piémont de Lourdes: le gisement de Biscaye (Hautes Pyrénées, France). Étude palynologique, sédimentologique et géomorphologique. [Upper Pleistocene and Holocene in the foothills of 
Lourdes: Palinologlogical, sedimentological and geomorphological research] Ph.D. thesis, University of Toulouse 2, 1982 (in French)

[25] Mardones M. Jalut G., La Tourbière de Biscaye (Alt 409m, Hautes Pyrénées): approche paléoécologique des 45000 dernières années [The Biscaye peatbog (409m, High Pyrenees): palaeoecological research from tha last 45000 years] Pollen et Spores, 1983, 25, 163-21 (in French)

[26] Jalut, G., Andrieu, V., Delibrias, G., Fontugne, M., Pagès, P. Palaeoenvironment of the Valley of Ossau (Western French Pyrénées) during the last 27000 years. Pollen et Spores, 1988, 30, 357-394

[27] Jalut G., Le paléoenvironnement de la moitie occidentale du versant nord des Pyrénées de 40.000 BP á l'actuel: Étapes de la deglaciation et Histoire de la Vegetation. [Palaeoenvironment of the western half of the northern slope of the Pyrenees from 40.000 BP to present: deglaciation phases and Vegetation History] In: Cearreta, A., Ugarte, F. (Eds) The Late Quaternary in the Western Pyrenean Region. Serv. Edit. University of País Vasco, Bilbao. 1992, 125-141 (in French)

[28] Vilaplana J.M., Quaternary glacial Geology of Alta Ribagorça Basin (Central Southern Pyrenees). Acta Geologica Hispanica, 1983, 18, 3-4, 217-233

[29] Vilaplana J.M., Bordonau J., Dynamique sédimentaire lacustre de marge glaciaire: Le paléolac de Llestui (Noguera Ribagorçana - versant sud des Pyrénées). [Lacustrine sedimentary dynamics of margin glacier: The palaeolake of Llestui (Noguera Ribagorçana, southern slope of the Pyrenees] Bull. A.F.E.Q., 1989, 4, 219-224 (in French)

[30] Vilaplana JM., Montserrat J., Schlüchter C., Recent progress in Quaternary stratigraphy: the lake Llauset sequence in the Spanish Pyrenees. In Rose, J., Schlüchter, C (Eds) Quaternary Type Sections: Imagination or Reality? Balkema Rotterdam. 1989.113124

[31] Bordonau J., Els complexos glacio-lacustres relacionats amb el darrer cicle glacial als Pirineus. [Glacial-lacustrine complexes related to the last glacial cycle in the Pyrenees] Geoforma Ediciones, Logroño, 1992 (in Spanish)

[32] Jalut G., Montserrat J., Fontugne M., Delibrias, G., Vilaplana J., Julià R., Glacial to interglacial vegetation changes in the northern and southern Pyrenees: deglaciation, vegetation cover and chronology. Quatern. Sci. Rev., 1992, 11, 449-480

[33] Martínez de Pisón E., Alonso F., Algunas reflexiones sobre el glaciarismo en las montañas españolas [Some thoughts about glacialism of the spanish mountains] In: Homenaje a F. Ugarte. Cuadernos de Sección, Historia, 1992, 20, 109-121 (in Spanish)

[34] Peña J.L., Sancho C., Lewis C., McDonald E., Rhodes E., Datos cronológicos de las morrenas terminales del glaciar del Gállego y su relación con las terrazas fluvioglaciares (Pirineo de Huesca). [Chronological data of the end moraines of the Gallego Glacier and its related fluvioglacial terraces] In: Peña, J.L., Longares, L.A., Sánchez, M. (Eds). Geografía Física de Aragón. Univ. Zaragoza - Inst. Fernando el Católico, Zaragoza 2004,71-84 (in Spanish)

[35] Pallàs, R., Rodés A., Braucher R., Carcaillet J., Ortuño M., Bordonau J., et al., Late Pleistocene and Holocene glaciation in the Pyrenees: a critical review and new evidence from ${ }^{10} \mathrm{Be}$ exposure ages, south central Pyreneees. Quatern. Sci. Rev. 2006, 29372963

[36] Jiménez-Sánchez M., Farias P., New radiometric and geomorphologic evidences of a last glacial maximum older than 18 ka in SW European mountains: the example of Redes Natural Park (Cantabrian Mountains, NW Spain). Geodin. Acta, 2002, 15, 93

[37] Jiménez-Sánchez M., Ruiz-Zapata M.B., Farias P., Dorado M., Gil M.J., Valdeolmillos A., Paleoenvironmental research in Cantabrian Mountains: Redes Natural Park and Comella basin. In: Ruiz-Zapata, M.B., Dorado, M., Valdeolmillos, A., Gil, M.J., Bardají, T., Bustamante, I., Martínez, I. (Eds) Quaternary Climatic Changes and Environmental Crises in the Mediterranean Region. University of Alcalá de Henares, Madrid, 2002, 229-240

[38] Moreno A., Valero-Garcés B.L., Jiménez-Sánchez M., Domínguez-Cuesta M.J., Mata M.P., Navas A., et al., The last deglaciation in the Picos de Europa National Park (Cantabrian Mountains, northern Spain). J. Quatern. Sci. 2010, 25, 7, 1076-1091

[39] Serrano E., González-Trueba J.J., González García M., Mountain glaciation and paleoclimate reconstruction in the Picos de Europa (Iberian Peninsula, SW Europe). Quaternary Res., 2012, 78, 303-314

[40] Serrano E., González J.J., Turu V., Ros X., Cronología glaciar pleistocena en el valle del Trueba (Cordillera Cantábrica): primeras dataciones. [Pleistocene Glacial Chronology in Trueba Valley (Cantabrian Mountains). First absolute dates] Abstract of Proceedings of the XIIIth National Meeting on Quaternary- AEQUA, Andorra, 2011, 3-6 (in Spanish)

[41] Pallàs R., Rodés A., Braucher R., Bourlès D., Delmas M., Calvet M., et al., Small, isolated glacial catchments as priority targets for cosmogenic surface exposure dating of Pleistocene climate fluctuations, south- 
eastern Pyrenees. Geology, 2010, 38, 891-894

[42] Cowton T., Hughes P.D., Gibbard P.L., Palaeoglaciation of Parque Natural Lago de Sanabria, northwest Spain. Geomorphology, 2009, 108, 282-291

[43] Rodríguez-Rodríguez L. Jiménez-Sánchez $M$. Domínguez-Cuesta M.J., Rico M.T., Valero-Garcés B., Last deglaciation in northwestern Spain: New chronological and geomorphologic evidence from the Sanabria region. Geomorphology, 2011, 135, 48-65

[44] Jiménez-Sánchez M. Rodríguez-Rodríguez L., García Ruiz J.M., Domínguez-Cuesta M.J., Farias P., ValeroGarcés B., et al., A review of glacial geomorphology in northern Spain: Timing and regional variability during the last glacial cycle. Geomorphology, 2012, doi:10.106/j.-geomorph.2012.06.009

[45] Serrano E., González-Trueba J.J., Pellitero R., González García M., Gómez-Lende M., Quaternary glacial evolution in the Central Cantabrian Mountains (Northern Spain). Geomorphology, 2012, doi:10.106/j.-geomorph.2012.05.001

[46] García-Ruiz J.M., Moreno A., González-Sampériz P., Valero-Garcés B., Martí-Bono C., La cronología del último ciclo glaciar en las montañas del sur de Europa. Una revisión. [The chronology of the Last Glacial Cycle in the Southern European Mountains. A review], Cuaternario y Geomorfología, 2009, 24, 12, 35-46 (in Spanish with English abstract)

[47] Ehlers J., Gibbard P.L., Hughes P.D. (Ed.) Quaternary Glaciations -Extent and Chronology. A closer look. Developments in Quaternary Science, Vol 15. Amsterdam, 2011, Elsevier. 1126p

[48] Clark P.U., Dyke A.S., Shakun J.D., Carlson A.E., Clark J., Wohlfarth B., et al., The Last Glacial Maximum. Science, 2009, 235, 710-714

[49] Serrano E., Geomorfología glaciar del Alto Trueba (Burgos). [Glacial geomorphology of the Alto Trueba Valley (Burgos, Spain)] In: Meaza G., García J.C., Arnáez J. (Eds) Libro-Guía Excursiones. XI Jornadas de Campo de Geografía Física. Vitoria, Santander, Logroño, 1995, 91-102 (in Spanish)

[50] Turu V., Boulton G., Ros X., Peña-Monné J.L, Martí i Bono C., Bordonau J., et al., Structure des grands bassins glaciaires dans le nord de la péninsule ibérique: Comparaison entre les vallées d'Andorre (Pyrénées orientales), du Gallego (Pyrénées centrales) et du Trueba (Chaîne cantabrique) [Structure of the large glacial basins in the northern Iberian Peninsula, a comparison study: Andorra (Eastern Pyrenees), Gallego (Central Pyrenees) and Trueba (Cantabric range)]. Quaternaire, 2007, 18(4): 309325. 2007. (in French)

[51] Mugnier C., El karst de la region del Asón y su evolu- ción morfológica [The karst of the Asón región and its morphological evolution] Cuadernos de Espeleología, 1969, 4. 1-146 (in Spanish)

[52] Delannoy J.J., Moverand Ph., Contribution à la connaissance de la karstogenèse du massif de Peña Lavalle (Cantabria, Espagne) [Knowledge advances of the Peña Lavalle karstogenesis], Grottes et Gouffres, 1989, 111 (in French)

[53] Hughes P.D., Woodward J.C., Timing of glaciation in the Mediterranean mountains during the last cold stage. J. Quatern. Sci., 2008, 23, 575-588

[54] Stuiver M. Riemer, P.J., Riemer R.W., Calib Radiocarbon Calibration Program*, CALIB 6.0, 2009

[55] Alcaraz-Pelegrina J.M., Martínez-Aguirre A. Isotopic fractionation during leaching of impure carbonates and their effect on Uranium series dating. Quatern. Sci. Rev. 2005, 24, 2584-2593

[56] Zimmerman D.W. Thermoluminescence dating using fine grains from potery. Archaeometry, 1971, 13, 2952

[57] Aitken M.J., Thermoluminescence dating. Academy Press, London, 1985

[58] Arribas J.G., Millán M.A., Sibilia E., Calderón T., Factores que afectan a la determinación del error asociado a la datación absoluta por TL [Factors affecting error determination linked to TL absolute dating], Bol. Soc. Esp. Miner., 1990, 13, 141-147 (in Spanish)

[59] Fuchs M., Owen L.A., Luminiscence dating of glacial and associated sediments: review, recommendations and future directions. Boreas, 2008, 37, 636-659

[60] Thrasher I.M., Mauz B., Chiverrel R.C., Lang A. Luminescence dating of glaciofluvial deposits: a review. Earth-Sci. Rev, 2009, 97, 133-146

[61] Krüger, J., Kjær, K.H. A data chart for field description and genetic interpretation of glacial diamicts and associated sediments - with examples from Greenland, Iceland and Denmark, Boreas, 1999, 28, 386-402

[62] Ballantyne C.K., Paraglacial geomorphology. Quatern. Sci. Rev., 2002, 21, 1935-2017.

[63] Mercier D., Paraglacial and paraperiglacial landsystems: concepts, temporal scales and spatial distribution. Géomorphologie, 2008, 4, 223-234.

[64] Mercier D, Étienne S. (Eds) Paraglacial geomorphology: processes and paraglacial context. Geomorphology, 2008, 95, 1-102.

[65] Duller G.A.T., Wintle A.G., Hall A.M., Luminescence dating and its application to key pre-Late Devensian sites in Scotland. Quaternary Sci. Rev., 1995, 14, 495-519

[66] Bøe, A.G., Muray, A., Dahl, S.O., Resetting of sediments mobilised by the LGM ice-sheet in southern Norway. Quat. Geochronology, 2007, 2, 222-228 
[67] Thomas P.J., Murray A.S., Kjaer K.H., Funde S., Larsen E., Optically stimulated luminescence (OSL) dating of glacial sediments from Artic Russia depositional bleaching and methodological aspects. Boreas, 2006, 35, 587-599

[68] Duller G.A.T. Single-grain optical dating of Quaternary sediments: why aliquot size matters in luminescence dating, Boreas, 2008, 37, 589-612

[69] Gillespie A., Molnar P. Asynchronous maximum advances of mountain and continental glaciers. Rev. Geophys.1995, 33, 311-364

[70] Ivy-Ochs, S., Kerschner H., Reuther A., Preusser F. Heine K., Maisch M., et al., Chronology of the last glacial cycle in the European Alps. J. Quatern. Sci., 2008, 23 (6-7), 559-573

[71] Moreno A., González-Sampériz P., Morellón M., Valero-Garcés B.L., Fletcher W.J., Northern Iberian abrupt climate change dynamics during the last glacial cycle: A view from lacustrine sediments. Quatern. Sci. Rev., 2012, 36, 159-153

[72] Gómez-Orellana L., Ramil-Rego P., Muñoz-Sobrino C., The Würm in NW Iberia, a pollen record from Area Longa (Galicia). Quaternary Res. 2007, 67, 438-452

[73] Sánchez-Goñi M.F., Loutre M.F., Crucufix M., Peyron O., Santos L. Duprat J., et al., Increasing vegetation and climate gradient in Western Europe over the Last Glacial Inception (122-110ka): data-model comparison. Earth Planet. Sc. Lett., 2005, 231, 1-2, 111-130

[74] Reitner J., Glacial dynamics at the beginning of Termination 1 in the Eastern Alps and their stratigraphic implications Quatern. Int., 2007, 164-165, 64-84

[75] Spötl C., Mangini A., U/Th age constraints on the absence of ice in the central Inn Valley (eastern Alps, Austria), during Marine Isotope Stages 5c to 5a. Quaternary Res., 2006, 66, 167-175

[76] Preusser F.,Geyh M.A., Schlüchter C., Timing of Late Pleistocene climate change in lowland Switzerland. Quatern. Sci. Rev. 2003, 22, 1435-1445

[77] Guitier F., Triganon A., Andrieu-Ponel V., Ponel P., Hébrard J-P., Nicoud G., et al., First evidence of "in situ" Eemian sediments on the high plateau of Evian (Northern Alps, France): Implications for the chronology of the Last Glaciation. Quatern. Sci. Rev., 2005, 24, 35-47

[78] Hughes P.D., Fenton C.R., Gibbard P.L., Quaternary Glaciations of the Atlas Mountains, North Africa. In: Ehlers J., Gibbard P.L., Hughes P.D. (Ed.) Quaternary Glaciations -Extent and Chronology. A closer look. Developments in Quaternary Science, Vol 15. Amsterdam, 2011, Elsevier. 1065-1074

[79] Palacios D., Andrés N., Marcos J., Vázquez-Selem L. (2012) Glacial landforms and their paleoclimatic sig- nificance in Sierra de Guadarrama. Central Iberian Peninsula. Geomorphology, 139-140, 67-78

[80] Palacios D., Marcos J., Vázquez-Selem L. (2011) Last Glacial Maximum and Deglaciation of Sierra de Gredos, Central Iberian Peninsula. Quatern. Int., 233, 1626

[81] Andrieu V., Eicher U, Reille M., La fin du dernier pléniglaciare dans les Pyrénées (France): données polliniques, isotopiques et radiométriques. [The end of Last Glacial Maximum in the Pyrenees] CR Acad. Sci. de Paris, 1993, 316-II, 245-250 (in French)

[82] Sánchez Goñi M-F., Hannon G., High-altitude vegetational pattern on the Iberian Mountain chain (north-central Spain) during the Holocene. Holocene 1999, 9, 39-5

[83] García-Ruiz J.M., Valero-Garcés B.L., Martí-Bono C., González-Sampériz P., Asynchroneity of maximum glacier advances in the central Spanish Pyrenees. J. Quatern Sci, 2003,18 (1), 61-72

[84] Sancho C. Peña J.L., Lewis C., McDonald E., Rhodes E., Preliminary dating of glacial and fluvial deposits in the Cinca river valley (NE Spain): Chronological evidences for the Glacial Maximum in the Pyrenees? In: Ruiz M.B. (Ed) Quaternary Climatic Changes and environmental crises in the Mediterranean region. Univ. Alcalá de Henares-INQUA, 2003, 169-173

[85] González-Sampériz P, Valero-Garcés B.L., GarcíaRuiz J.M., Jalut G., Moreno A., Navas A., et al., La deglaciación temprana en el Pirineo Central: el registro de El Portalet. [The early deglaciation in the Central Pyrenees: El Portalet] Geotemas, 2004, 5, 5, 101-104 (in Spanish)

[86] González Sampériz P, Valero-Garcés B.L., Carrión J.S., Peña-Monné J.L., García-Ruiz J.M., Martí-Bono C., Glacial and Lateglacial vegetation in northeastern Spain: New data and review. Quatern Int., 2005, 140-141, 4-20

[87] González Sampériz P, Valero-Garcés B.L., Moreno A., Jalut G., García-Ruiz J.M., Martí-Bono C., et al.., Climate variability in the Spanish Pyrenees during the last 30,000 yr revealed by the El Portalet sequence. Quaternary Res., 2006, 66, 38-52

[88] Lewis C.J., McDonald E.V., Sancho C., Peña J.L., Rhodes E.J., Climatic implications of correlated Upper Pleistocene glacial and fluvial deposits on the Cinca and Gállego rivers (NE Spain) based on OSL dating and soil stratigraphy. Global Planet. Change, 2009, 67, 141-152

[89] Delmas M., Calvet M., Gunnell M., Braucher R., Bourlès D., Palaeogeography and ${ }^{10} \mathrm{Be}$ exposure-age chronology of Middle and Late Pleistocene glacier systems in the northern Pyrenees: implications for 
reconstructing regional palaeoclimates. Palaeogeogr., Palaeocl., 2011, 305:109-122

[90] Bordonau J.; Vilaplana J.M. and Fontugne M. The glaciolacustrine complex of Llestui (Central Southern Pyrenees): A key-locality for the chronology of the last glacial cycle in the Pyrenees. CR Acad. Sci. Paris, 1993, 316: 807-813

[91] Jalut G., Turu i Michels V., Deboubat J.J., Otto T., Ezquerra J., Fontugne M., et al., Paleoenvironmental studies in NW Iberia (Cantabrian range) Vegetation history and synthetic approach of the Last Deglaciation phases in wstern Mediterranean. Palaeogeogr. Palaeocl., 2010, 297, 2, 330-350

[92] Pérez-Alberti A., Valcárcel-Díaz M., Martini I.P., Pascucci V., Andrucci S. Upper Pleistocene glacial valley-junction sediment in Pías, Trevinca Mountains, NW Spain. In: Martini, I.P., French, H.M., PérezAlberti, A. (Ed.), Ice-Marginal and Periglacial Processes and Sediments. Geol. Soc. London Special Publications, 2011, 354, 93-110

[93] Straus L.G., González-Morales M., Farrand W.R., Hubbard W.J., Sedimentological and Stratigraphic Observations in El Mirón, a Late Quaternary Cave Site in the Cantabrian Cordillera, Northern Spain. Geoarchaeology. 2001, 16, 5, 603-630

[94] Courty M.A., Vallverdu J., The Microstratigraphic
Record of Abrupt Climate Changes in Cave Sediments of the Western Mediterranean. Geoarchaeology, 2001, 16, 5, 467-500

[95] Ellwood B.B., Harrold F.B., Benoist S.L., Straus L.G., González-Morales M., Petruso K., et al., Paleoclimate and Intersite orrelations from Late Pleistocene/Holocene Cave Sites: Results from Southern Europe. Geoarchaeology, 2001, 16, 4, 433-463

[96] Bond G., Broecker W., Johnsen S., McManus J., Labeyrie L., Jouzel J., et al., Correlations between climate records from North Atlantic sediments and Greenland ice. Nature, 1993, 365, 143-147

[97] Cacho I, Grimalt J.O., Pelejero C., Canals M., Sierro F.J., Flores J.A., et al., Dansgaard - Oescher and Heinrich event imprints in Alboran Sea temperatures. Paleoceanography 1999, 14, 698-70

[98] Frigola J., Moreno A., Cacho I., Canals M., Sierro F.J., Flores J.A., et al., Evidence of abrupt changes in Western Mediterranean Deep Water circulation during the last $50 \mathrm{kyr}$ : a high resolution marine record from the Balearic Sea. Quatern. Int., 2008, 181, 88104.

[99] Davis P.Th, Menounos B., Osborn G., Holocene and latest Pleistocene alpine glacier fluctuations: a global perspective. Quatern. Sci. Rev., 2009, 28, 2021-2033 